\title{
A POLÍTICA NACIONAL DE IRRIGAÇÃO E O USO DE AGROTÓXICOS NO BRASIL: CONTAMINAÇÃO E INTOXICAÇÕES NO CEARÁ
}

\section{Bernadete Maria Coelho Freitas*}

\author{
Larissa Mies Bombardi** \\ Universidade de São Paulo
}

Resumo: A ampliação do mercado e o incentivo ao uso de agrotóxicos vêm ocorrendo de forma sistemática no Brasil. 0 País tornou-se o maior consumidor de agrotóxicos do mundo desde 2008, suscitando diversas consequências para a sociedade e o ambiente. 0 objetivo deste artigo, nesse sentido, é analisar a relação entre o uso de agrotóxicos e a Política Nacional de Irrigação no Brasil, no contexto da mundialização do capital na agricultura, evidenciando sua espacialização em áreas de perímetros irrigados do Ceará, mais especificamente no Baixo Jaguaribe, leste do referido estado. Compreende-se que as problemáticas decorrentes do uso de agrotóxicos intensificaram-se no Baixo Jaguaribe após a implantação da Política Nacional de Irrigação, favorecendo o avanço do agronegócio. 0 estudo baseia-se em pesquisas bibliográficas, trabalhos de campo e mapeamentos a partir de dados oficiais. A análise mostra a necessidade de reavaliar as políticas públicas e as legislações atuais que incentivam o uso de agrotóxicos, dentre as quais a política de irrigação e a legislação referente à pulverização aérea, frente aos danos causados ao ambiente e aos sujeitos sociais do campo e da cidade. A efetivação de políticas públicas que priorizem a agricultura camponesa e agroecológica torna-se imprescindível no Brasil, pela possiblidade de relação mais saudável com a natureza e por fortalecer a justiça social no campo.

Palavras-chave: Intoxicações. Agrotóxicos. Política Nacional de Irrigação. Campesinato. Agronegócio.

\section{THE NATIONAL IRRIGATION POLICY AND THE USE OF PESTICIDE IN BRAZIL: CONTAMINATION AND POISONING IN CEARÁ}

Abstract: The expansion of the mart and the incentive to the use of pesticides have been occurring systematically in Brazil. Since 2008 the country has become the largest consumer of pesticides in the world, resulting in consequences for both, society and the environment. The aim of this article is to analyze the use of pesticides and how it relates to the National Irrigation Policy in Brazil, in the context of the globalization of capital in agriculture, showing its spatialization in areas of irrigated perimeters in the state of Ceará, specifically in the Lower Jaguaribe watershed, in the state's east region. It is understood that the problems arising from the use of pesticides were intensified in Lower Jaguaribe after the implementation of the National Irrigation Policy, which favored the advance of agribusiness. The study is based on literature research, field work and mapping from official data. The analysis shows the need to re-evaluate public policies and current legislation that encourage the use of pesticides, including irrigation policy and legislation on aerial spraying, and its damages to the environment and to the affected population in the countryside and in urban areas. The implementation of public policies that prioritize peasant and agroecological agriculture becomes essential in Brazil, due to the possibility of achieving a more balanced interaction with nature and to reinforce social justice in the countryside.

Keywords: Poisoning. Pesticides. National Irrigation Policy. Peasantry. Agribusiness.

\section{LA POLÍTICA NACIONAL DE RIEGO Y EL USO DE PESTICIDAS EN BRASIL: CONTAMINACIÓN E INTOXICACIONES EN EL CEARÁ}

Resumen: La ampliación del mercado y el incentivo al uso de pesticidas vienen ocurriendo de forma sistemática en Brasil. El país se convirtió en el mayor consumidor mundial de pesticidas desde 2008, lo que produce diversas consecuencias para la sociedad y el medio ambiente. En ese sentido, el objeto del presente artículo es analizar la relación entre el uso de pesticidas y la Política Nacional de Riego en Brasil, en el contexto de mundialización del capital en la agricultura, demostrando su espacialización en áreas de los perímetros regados de la provincia Ceará, más específicamente en el Baixo Jaguaribe, al este de dicha provincia. Se comprende que los problemas que resultan del uso de pesticidas se intensificaron en el Baixo Jaguaribe tras la implementación de la Política Nacional de Riego, que favorece el avance del agronegocio. El estudio se basa en investigaciones bibliográficas, trabajos de campo y mapeamientos con base en datos oficiales. El análisis muestra la necesidad de reevaluar las políticas públicas y las legislaciones actuales que incentivan el uso de pesticidas, entre las cuales se encuentra la política de riego y la legislación referente a la pulverización aérea, frente a los daños causados al ambiente y a los sujetos sociales del campo y de la ciudad. La efectividad de políticas públicas que prioricen la agricultura campesina y agroecológica es imprescindible en Brasil, ya que posibilitará una relación más sana con la naturaleza, así como audará a fortalecer la justicia social en el campo.

Palabras clave: Intoxicaciones. Pesticidas. Política Nacional de Riego. Campesinado. Agronegocio.

*Doutora em Geografia Humana pela Universidade de São Paulo. Desenvolve atividades de pesquisa e extensão em parceria com o Núcleo TRAMAS/UFC e com o Programa de Extensão da FAFIDAM/UECE. E-mail: bernadetegeo@gmail.com.

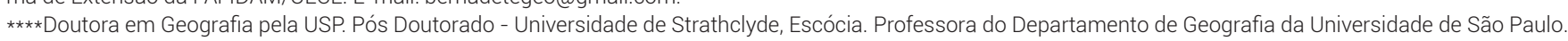
Endereço: Av Professor Lineu Prestes, 338. Departamento de Geografia. Cidade Universitária. São Paulo - SP. CEP 05508-000. E-mail: larissab@usp.br 
O objetivo deste artigo é analisar a relação entre o uso de agrotóxicos e a Política Nacional de Irrigação no Brasil, no contexto da mundialização do capital na agricultura (CHESNAIS, 1996; OLIVEIRA, 2015), tomando como referência sua espacialização no estado do Ceará, especificamente no Baixo Jaguaribe. Compreende-se que as problemáticas decorrentes do uso de agrotóxicos nessa região intensificaram-se com a implantação e o avanço da Política Nacional de Irrigação, principalmente após a década de 1990, com a expansão da agricultura capitalista, por meio da inserção do agronegócio nas áreas de Perímetros Públicos Irrigados (FREITAS, 2010; 2011; RIGOTTO, 2011).

De acordo com o IBGE (1990; 2002), o Baixo Jaguaribe é composto pelos municípios de Alto Santo, Ibicuitinga, Jaguaruana, Limoeiro do Norte, Morada Nova, Palhano, Quixeré, Russas, São João do Jaguaribe e Tabuleiro do Norte, pertencente ao Vale do Jaguaribe, localizado ao leste do Ceará. Essa região constitui o primeiro espaço efetivamente reocupado no século XVII, especialmente por contar com o maior rio do estado, o Jaguaribe. Tornou-se ao longo dos anos uma das principais áreas de planejamento do Estado, em função das suas características ambientais, laborais etc. (FREITAS, 2010).

Souza et al (2002), ao realizarem um estudo referente à classificação das unidades geoambientais do Baixo Jaguaribe, destacam a fertilidade dos solos dessa região nas suas feições predominantes, favorecendo a implementação de atividades agrícolas: a presença dos cambissolos na Chapada do Apodi, dos podzólicos dos tabuleiros areno-argilosos e das aluviões das planícies fluviais. Apesar dos solos férteis, o contexto de intensas irregularidades de precipitações e longos períodos de secas dificultaram o acesso à água, características inerentes ao contexto do semiárido nordestino.

Essas questões, associadas às crises de atividades econômicas (a exemplo da cera de carnaúba), influenciaram a atuação do estado através da implantação dos Perímetros Irrigados, objetivando atender tais demandas, ampliar a produtividade e mercantilizar esses espaços. Nesse contexto, após a década de 1970, o Baixo Jaguaribe passou a incorporar essa política pública, tornando-se, atualmente, uma das regiões do Ceará mais expressivas em relação à produção agrícola de commodities (fruticultura irrigada para exportação), bem como acerca dos impactos do uso de agrotóxicos.

Após a segunda metade do século XX, com o avanço do capitalismo no campo, os agrotóxicos passaram a ser utilizados de forma mais intensa no Brasil. Esse processo relaciona-se ao contexto mundial pós-Segunda Grande Guerra, e sua materialização se deu com a denominada "revolução verde" através da intervenção do Estado, a exemplo da Política Nacional de Irrigação e de legislações específicas relacionadas ao crédito agrícola, aos agrotóxicos etc.

Com o avanço do neoliberalismo, após as últimas décadas, a agricultura brasileira passou a assumir novos papéis no âmbito do processo de mundialização do capital (CHESNAIS, 1996), tendo rebatimentos em relação ao mercado de agrotóxicos que, sob o controle de empresas oligopolistas, favorece a ampliação da sujeição da renda da terra ao capital (MARTINS, 1981; FREITAS, 2017), conforme analisado em outro trabalho (BOMBARDI, 2016).

\begin{abstract}
Observa-se [...] que as seis empresas que têm maior participação nas vendas de agrotóxicos no Brasil, sozinhas, controlam praticamente $60 \%$ do mercado. Observa-se também que se trata de empresas transnacionais com capital de origem na Suíça (Syngenta), Estados Unidos (Monsanto e Dow), Alemanha (Bayer e Basf) e Holanda/Israel (Milenia). Notadamente, percebe-se a subordinação da agricultura brasileira ao capital internacional. Arcaico e moderno se fundem: intoxicações, doenças e mortes são o outro lado da moeda desta "moderna agricultura" que demanda toneladas de agrotóxicos produzidos com tecnologia de ponta, pelas maiores transnacionais do setor químico mundial. (BOMBARDI, 2016, p. 27)
\end{abstract}

Atualmente, a ampliação do mercado e o incentivo ao uso de agrotóxicos vêm ocorrendo de forma sistemática no Brasil, conforme alerta do Dossiê ABRASCO (CARNEIRO; AUGUSTO; RIGOTTO et al., 2015). O estudo mostra que a partir de 2008 o Brasil tornou-se o maior consumidor de agrotóxicos do mundo, refletindo no avanço do mercado de agrotóxicos no País, crescendo $190 \%$ entre os anos de 2002 e 2012, superando o crescimento mundial, de 93\%, nesse período. Em 2016, o Relatório Nacional de Vigilância em Saúde de Populações Expostas a Agrotóxicos, divulgado pelo Ministério da Saúde, evidencia o aumento de $13 \%$ das vendas de agrotóxicos no País, com faturamento líquido de US\$ 12,2 bilhões, em 2014, o equivalente a R\$ 25 bilhões (MINISTÉRIO DA SAÚDE, 2016).

No Ceará, a relação entre comercialização de agrotóxicos por área plantada ampliou consideravelmente entre 2012 e 2013 , saltando de $7 \mathrm{~kg} / \mathrm{ha}$ para $19,75 \mathrm{~kg} / \mathrm{ha}$, respectivamente, ficando atrás apenas do Rio de Janeiro $(135,45 \mathrm{~kg} / \mathrm{ha})$ e São Paulo (35,72kg/ha), no ano de 2013 (MINISTÉRIO DA SAÚDE, 2016).

Conforme foi identificado em trabalho anterior (BOMBARDI, 2013, p. 1), estamos diante de "uma forma silenciosa de violência no campo, que é resultado das intoxicações causadas pelo uso de tais substâncias. Essas intoxicações, além de serem em número 
extremamente elevado, têm levado à morte um número significativo de pessoas". Somente entre o período de 2007 a 2014 foram registradas 34 mil notificações de intoxicações por agrotóxicos, ressaltando que, "de acordo com estimativas do Ministério da Saúde, para cada evento de intoxicação por agrotóxicos notificado, há outros 50 não notificados" (PERESA; ROZEMBERGA; ALVES et al., 2001, p. 565). Trata-se, nesse sentido, de um quadro alarmante em relação aos efeitos do uso de agrotóxicos e sem o devido monitoramento, diante das limitações dos sistemas públicos de informações, responsáveis pelo controle de tais notificações (BOCHNER, 2007).

Segundo o Art. $1^{\circ}$, Inciso IV, do Decreto n. 4.074, de janeiro de 2002, que regulamenta a Lei n. 7.802, de 11 de julho de 1989 - dispondo sobre os parâmetros de uso, produção, comercialização, fiscalização etc. - -, define os agrotóxicos e afins como:

\begin{abstract}
produtos e agentes de processos físicos, químicos ou biológicos, destinados ao uso nos setores de produção, no armazenamento e beneficiamento de produtos agrícolas, nas pastagens, na proteção de florestas, nativas ou plantadas, e de outros ecossistemas e de ambientes urbanos, hídricos e industriais, cuja finalidade seja alterar a composição da flora ou da fauna, a fim de preservá-las da ação danosa de seres vivos considerados nocivos, bem como as substâncias e produtos empregados como desfolhantes, dessecantes, estimuladores e inibidores de crescimento. (MINISTÉRIO DA AGRICULTURA, PECUÁRIA E ABASTECIMENTO, 2002)
\end{abstract}

0 referido Decreto afirma que o uso de agrotóxicos se destina, dentre outras finalidades, "(...) a proteção de florestas, nativas ou plantadas, e de outros ambientes urbanos, hídricos e industriais (...) a fim de preserválas da ação de seres vivos considerados nocivos (...)". Vale lembrar, entretanto, que os agrotóxicos, enquanto "biocida", termo que designa "mata a vida" (LONDRES, 2011), podem gerar, além da contaminação ambiental, diversas implicações à saúde humana, conforme discutem Rosa, Pessoa e Rigotto (2011, p. 222-223), ao tomarem como referência diversos estudiosos sobre a questão:

Como biocidas, os agrotóxicos interferem em mecanismos de sustentação da vida que são comuns também aos seres humanos e, portanto, são associados a uma ampla gama de danos à saúde, como por exemplo: alterações cromossômicas: inseticidas organofosforados e carbamatos; teratogênese: fungicidas fentalamidas; herbicidas fenoxiacéticos; infertililidade masculina: nematicidas dibromocloropropano etc; carcinogênese: fungicidas ditiocarbamatos, herbicidads dinitrifenóis e pentaclorofenol, fenociacéticos etc.; neurotoxidade: organofosforados e organiclorados; interferentes endócrinos: alquilfenóis, glifosato, ácido diclorofenoxiacético, praguicidas organoclorados, metolacloro, acetocloro, alacloro, clorpirifós, metoxicloro e piretóides sintéticos; doenças hepáticas: organocloratos, herbicidas dipiridilos; doenças respiratórias: inseticidas piretróides sintéticos, ditiocarbamatos, dipiridilos; doenças renais: organoclorados; doenças hermatológicas: organofosforados e carbamatos, ditiocarbamatos, dioridilos.

A ideia de "proteção" fortalece, inclusive, a concepção de "defensivos agrícolas", apresentada pelo Projeto de Lei (PL) 3200/15, de autoria do deputado federal Covatti Filho (PP-RS), que propõe a substituição da atual Lei de Agrotóxicos (7.802/89). A mudança inclui a passagem do nome "agrotóxicos" para "defensivos fitossanitários e produtos de controle ambiental", amenizando as impressões sobre os efeitos que podem causar. Vale ressaltar que o termo "agrotóxico" foi criado, após a década de 1980, pelo movimento ambientalista brasileiro para denominar os "venenos agrícolas", como forma de estabelecer diálogo e alertar a sociedade sobre suas graves consequências (LONDRES, 2011).

O uso intenso de agrotóxicos e seus rebatimentos têm se constituído um problema de saúde pública, instigando pesquisadores de todo o País, em diferentes áreas do conhecimento, a realizarem pesquisas científicas que problematizem e espacializem os desdobramentos do uso de agrotóxicos, cujos impactos negativos vêm sendo evidenciados em diversos espaços brasileiros, dentre os quais o estado do Ceará. Nesse contexto, este artigo pretende somar e contribuir com esse debate, a partir de uma abordagem do pensamento crítico.

A metodologia adotada compreende pesquisas bibliográficas de diferentes ramos da ciência, dentre os quais estudos que analisam o tema dos agrotóxicos e das políticas públicas (como geografia, medicina e direito); trabalhos de campo nos Perímetros Irrigados do Baixo Jaguaribe, Ceará, no período de 2013 a 2017, onde foram realizados registros audiovisuais, entrevistas com camponeses e trabalhadores rurais (assalariados), além da participação em reuniões e audiências com representantes de órgãos do Estado, movimentos sociais e outras entidades; e mapeamento a partir de dados oficiais do Sistema de Informação de Agravos de Notificação (SINAN), do Ministério da Saúde, referente às intoxicações por agrotóxicos de uso agrícola, visando correlacionar com as implicações do uso de agrotóxicos nas áreas de Perímetros Irrigados do Ceará.

O texto aponta elementos da ascendência e do incentivo ao uso de agrotóxicos no Brasil, no contexto do avanço do neoliberalismo e da mundialização do capital monopolista na agricultura. Evidencia como o estado do Ceará incorporou tais parâmetros, atingindo as áreas de perímetros irrigados e ampliando, consequentemente, o 
agronegócio e o uso de agrotóxicos. Apresenta, por fim, as implicações do uso de agrotóxicos, dentre as quais as intoxicações e contaminação por agrotóxicos, tomando como referência a região do Baixo Jaguaribe, leste do Ceará.

A ascendência e o incentivo ao uso de agrotóxicos no Brasil no contexto do neoliberalismo e da mundialização do capital monopolista na agricultura

Após a década de 1960, o uso de agrotóxicos passou a ser disseminado e incentivado no Brasil, resultante do avanço do capitalismo no campo, amparado pelo discurso de ampla produtividade da agricultura, sob a prelação do remate da fome, questão não solucionada, mesmo após intensa produtividade agrícola. Esse processo efetivouse por meio do modelo tripé adotado no País, a partir de uma aliança entre o Estado, o capital privado nacional e o capital privado internacional (OLIVEIRA, 1981). O País, com base nessa aliança, passou a incorporar a indústria de agrotóxicos, oriunda das grandes guerras, momento no qual os países centrais possuíam grandes estoques e necessitavam de mercados consumidores (LONDRES, 2011).

Essa questão pode ser verificada na análise de Machado e Machado Filho (2014, p. 92) quando afirmam que, ao final da I Guerra Mundial (1914-1918), os alemães possuíam grandes estoques de nitratos, usados na fabricação de explosivos, e a indústria química os reciclou, introduzindo-os na agricultura. Os autores esclarecem que os agrotóxicos não foram criados para agricultura nem tampouco para trazer benefícios à humanidade, como mostram na sequência.

Como frutos da guerra, os nitratos foram criados para
matar o homem e destruir suas plantações e não
para beneficiar a humanidade (...). Os agrotóxicos,
igualmente, foram desenvolvidos para a guerra e
não para a agricultura! O DDT, criado por Paul Muller,
na Suíça, em 1939, foi inicialmente usado na guerra:
lançado como inseticida para "limpar" as áreas de
combate das tropas norte-americanas, primeiro na
Itália, onde havia uma epidemia de tifo (...) O mesmo
se deu com o "agente laranja", empregado pelos norte-
americanos nas guerras contra o Japão e o Vietnã.
Esse veneno, que tem a dioxina como princípio ativo,
foi responsável pela destruição de dezenas de milhares
de quilômetros quadrados de florestas e plantações
[...] além das mortes humanas e das sequelas deixadas
nas populações sobreviventes. (MACHADO, MACHADO
FILHO, 2014, p. 92)

É nesse contexto que amplia o incentivo ao uso de agrotóxicos, nas décadas de 1960 e 1970. Londres (2011) destaca as estratégias do Estado, por meio da política de crédito agrícola conjugado à obrigatoriedade do uso de agrotóxicos, e pela oferta de recursos para criação de empresas nacionais e subsidiárias internacionais de insumos agrícolas, momento em que a FAO e o Banco Mundial promoveram a propagação do pacote tecnológico da "Revolução Verde", sob o discurso da necessidade de derrotar a fome no mundo.

No cenário mundial, a FAO (órgão das Nações
Unidas para a Alimentação e Agricultura) e o Banco
Mundial foram os maiores promotores da difusão do
pacote tecnológico da Revolução Verde. No Brasil,
uma série de políticas levada a cabo por diferentes
governos cumpriu o papel de forçar a implementação
da chamada "modernização da agricultura". Neste
processo teve papel central a criação, em 1965, do
Sistema Nacional de Crédito Rural, que vinculava a
obtenção de crédito agrícola à obrigatoriedade da
compra de insumos químicos pelos agricultores. Outro
elemento-chave foi a criação, em 1975, do Programa de
Defensivos Agrícolas, no âmbito do II Plano Nacional
de Desenvolvimento (PND), que proporcionou recursos
financeiros para a criação de empresas nacionais
e a instalação no País de subsidiárias de empresas
transnacionais de insumos agrícolas. (LONDRES, 2011,
p. 17-18)

Os perímetros irrigados foram implantados nesse contexto, no âmbito da Política de Irrigação, após a década de 1960. Os perímetros foram pensados pela Superintendência de Desenvolvimento do Nordeste (SUDENE) e operacionalizados através do Departamento Nacional de Obras Contra as Secas (DNOCS). 0 projeto foi concebido no âmbito do governo militar (1964-1985), sob o discurso de reforma agrária e colonização, como estratégia para amenizar os conflitos sociais e ampliar a produtividade do campo no semiárido nordestino, integrando-se ao capital nacional, por sua vez, associado ao capital internacional (OLIVEIRA, 1981; FREITAS, 2010). Nesse sentido, Diniz (2002, p. 42) afirma que:

O projeto dos perímetros de irrigação fundamenta-
se juridicamente no Estatuto da Terra (Lei n. 504, de
30 de novembro de 1964), aprovado na vigência da
ditadura militar, e traz duas propostas bem nítidas no
que se refere à política fundiária: a Reforma Agrária e a
Colonização, sem que uma excluísse a outra. Sabe-se,
entretanto, que a colonização foi uma medida paliativa
(...) no intuito de desmobilizar os crescentes conflitos
ocorridos no campo, colocando-se também como
uma forma de aumentar a produtividade no meio rural,
integrando-o ao contexto do capitalismo nacional.

Com base nesses propósitos os perímetros passaram a incorporar, seletivamente, alguns espaços nordestinos detentores das condições que atenderiam aos interesses do capital, processo também denominado de "modernização da agricultura", conforme destacamos em outro trabalho (PONTES; GADELHHA; FREITAS et al., 2013).

As políticas agrícolas no semiárido brasileiro, desde os 
anos 1960, vêm acompanhadas da implantação dos perímetros irrigados como estratégia geopolítica de expansão seletiva da fronteira agrícola, na perspectiva da indução do desenvolvimento. Os perímetros irrigados são áreas delimitadas pelo Estado para implantação de projetos públicos de agricultura irrigada que, em geral, possuem significativo potencial agricultável, caracterizado pelos solos férteis, presença hídrica, clima favorável e abundante força de trabalho. Estes elementos conjugados às infraestruturas implementadas (canais, piscinas etc.) favorecem ampla produtividade agrícola. Tal estratégia é, agora, retomada pelo governo com grande ênfase e, certamente, vem ao encontro deste capital transnacional que aqui se instala para produzir commodities agrícolas, a partir de terra, água e mão de obra, facilidades de infraestrutura e de financiamento, além de condições políticas e institucionais favoráveis. (p. 3.214)

Com a expansão do neoliberalismo, após a década de 1990, a Política Nacional de Irrigação sofreu mudanças e o uso de agrotóxicos tornou-se cada vez mais intenso, momento em que o agronegócio passou a constituir-se o modelo adotado, de forma predominante, no Brasil, objetivando a produção de commodities (mercadorias) a ser ofertada ao mercado mundial, processo que envolveu a intensificação da aliança do modelo tripé mencionada.

Os subsídios para a agricultura de base camponesa a responsável pela produção de alimentos para consumo interno - passam a ser questionados de forma enfática, colocando em risco a soberania alimentar do País (OLIVEIRA, 2015). Os Estados neoliberais substituem a política de soberania alimentar pela política de segurança alimentar, ao passo que criam as condições de controle do mercado dos estoques de alimentos governamentais pelas empresas monopolistas mundiais, conforme esclarece Oliveira (2015, p. 240).

\begin{abstract}
Com o neoliberalismo, passou a ocorrer, em primeiro lugar, a pregação neoliberal contra os subsídios, obviamente, uma postura contra a agricultura de base familiar camponesa. Em segundo lugar, os governos neoliberais passaram a reduzir os estoques governamentais de alimentos, por uma sub-reptícia substituição das políticas de soberania alimentar pela política de segurança alimentar. Em terceiro lugar, as políticas de segurança alimentar dos Estados neoliberais passaram a substituir os estoques governamentais pelos estoques das empresas monopolistas mundiais, tornando o mercado o único regulador do abastecimento alimentar das populações nacionais. Em quarto lugar, foi criada em 1994 a Organização Mundial do Comércio (OMC), como órgão mundial de regulação e de decisões mundiais entre os países com contendas comerciais.
\end{abstract}

A agricultura brasileira passa a assumir novo lugar no mundo como integrante da mundialização do capital, estruturando-se, segundo Oliveira (2015, p. 240), "sobre uma tríade: a produção de commodities, as bolsas de mercadorias e de futuro e a formação das empresas monopolistas mundiais". Destarte, como parte das estratégias do Estado, as políticas públicas foram sendo redefinidas, bem como foram construídas novas legislações que serviram de estímulo à inserção do capital monopolista no campo.

Dentre esses estímulos podem-se mencionar os incentivos concedidos ao comércio de agrotóxicos pelo Estado brasileiro, por meio de isenções fiscais e tributárias etc., como mecanismos de atrair os empreendimentos do agronegócio, como ressalta a análise de Londres (2011, p 18-19), advertindo, ainda, sobre a existência de isenções complementares ofertadas por alguns estados:

Através do Convênio ICMS 100/97, o governo federal concede redução de $60 \%$ da alíquota de cobrança do ICMS (Imposto sobre Circulação de mercadorias e Serviços) a todos os agrotóxicos [...] Além disso, o Decreto 6.006/06' isenta completamente da cobrança de IPI (Imposto sobre Produtos Industrializados) os agrotóxicos fabricados a partir de uma lista de dezenas de ingredientes ativos (incluindo alguns altamente perigosos como o metamidofós e o endossulfan, que recentemente tiveram o banimento determinado pela ANVISA) [...] O Decreto 5.630/05 isenta da cobrança de PIS/PASEP (Programa de Integração Social/ Programa de Formação do Patrimônio do Servidor) e de COFINS (Contribuição para o Financiamento do Patrimônio da Seguridade Social) os "defensivos agropecuários classificados na posição 38.08 da NCM e suas matériasprimas". A posição 38.08 da NCM (Nomenclatura Comum do Mercosul) compreende produtos diversos das indústrias químicas como inseticidas, fungicidas e herbicidas. Além das isenções federais, há as isenções complementares determinadas por alguns estados [...]

No caso do Estado do Ceará, o levantamento realizado por Carneiro, Almeida, Teixeira et al. (2011), na Secretaria da Fazenda do Estado do Ceará (SEFAZ), evidenciam os meios legais pelos quais o Estado oferta reduções e isenções fiscais relativas ao agronegócio, constatando que no Estado do Ceará incidem sobre os agrotóxicos isenção total de ICMS, além das isenções concedidas pelos decretos federais de IPI e de PIS/PASEP e COFINS:

\begin{abstract}
a) Agrotóxicos isentos da cobrança de ICMS no Estado do Ceará, por força do Decreto n. 24.569, publicado em 31 de julho de 1997; b) Agrotóxicos com redução de $60 \%$ da alíquota de cobrança do ICMS nos demais estados da federação (à exceção daqueles que se manifestarem em sentido diverso), por força do Convênio n. 100/97, que teve sua vigência prorrogada até 31.12 .2012 ; c) Agrotóxicos isentos da cobrança de IPI, por força da Tabela de Incidência do IPI, apresentada no Decreto $n$. 6.006/06, de 28 de dezembro de 2006; d) Agrotóxicos isentos da cobrança de PIS/PASEP e de COFINS, por força do Decreto n. 5.630, de 22 de dezembro de 2005. (CARNEIRO; ALMEIDA; TEIXEIRA et al., 2011, p. 592)
\end{abstract}

Essas questões mostram que após a década de 1990 ampliou a "dependência" brasileira em relação

'Revogado pelo Decreto n. 7.660, de 23 de dezembro de 2011, que aprova Tabela de Incidência do Imposto sobre Produtos Industrializados (TIPI) 
ao capital internacional, ao passo que avançou a aliança do Estado brasileiro com o capital nacional e internacional, no contexto da mundialização do capital e do neoliberalismo. Ressalta-se que o papel do Estado permanece central nesse processo, como esclareceu Chesnais (2000, p. 14):

\begin{abstract}
A mundialização do capital não apaga a existência dos Estados nacionais, nem as relações políticas de dominação e de dependência entre eles. Ela acentuou, ao contrário, os fatores de hierarquização entre países. 0 abismo que separa os países que pertencem aos pólos da 'Tríade' (América do Norte, A Europa Ocidental e o Japão) (...) daqueles que sofrem a dominação do capital financeiro sem retorno (...).
\end{abstract}

As políticas públicas brasileiras foram atingidas por essas mudanças, inclusive aquelas direcionadas aos Perímetros Irrigados. Segundo diagnóstico sobre a irrigação no Brasil, realizado pelo Ministério da Integração Nacional (2008), o País implantou 97 projetos de irrigação', sendo 39 na jurisdição da Companhia de Desenvolvimento dos Vales do São Francisco e Parnaíba (CODEVASF), 38 do DNOCS instalados no Nordeste e 20 do próprio Ministério, por meio de convênios com diversas unidades da Federação.

0 referido diagnóstico mostra a redefinição dessa política, passando a denominar-se de Projeto Novo Modelo de Irrigação, prevendo o fortalecimento da parceria público-privada, sendo o agronegócio o vetor desse processo. Esses elementos podem ser percebidos nos objetivos específicos do Novo Modelo de Irrigação que visa "estimular o investimento privado em todas as fases do agronegócio da irrigação, orientar a produção para as oportunidades de mercado e redirecionar a participação do governo na atividade (...)" (MINISTÉRIO DA INTEGRAÇÃO NACIONAL, 2008, p. 12).

Essa orientação, por sua vez, partiu de outro estudo realizado pelo Banco Mundial (2004), também financiador dessa política, que considerou essa mudança necessária. O Banco Mundial (2004) apresentou diagnóstico e "sugestões" para as intervenções governamentais brasileiras, no sentido de priorizar o agronegócio nos perímetros públicos. De acordo com o Banco Mundial, o suposto "sucesso" dos perímetros irrigados seria resultado da inserção das empresas nesses projetos, após os anos de 1990, desconsiderando os impactos negativos por ele mesmo apontado:

Os perímetros que reúnem essas características obtiveram sucesso em seu desenvolvimento, como nos casos do Pólo de Petrolina e Juazeiro [..]. Os projetos Jaíba e Morada Nova, no Norte dos estados de Minas Gerais e do Ceará, respectivamente, constituem exemplos extremos de fracassos econômicos. Esse elevado retorno social gerado pela agricultura irrigada deve-se, em grande parte, ao envolvimento, a partir da década de 1990, de produtores empresariais nos projetos, os quais contribuíram para a reconversão dos cultivos tradicionais em produtos exportáveis de maior valor agregado e mais intensivos em mão-de-obra [...] Portanto, essa experiência demonstra que sistemas de produção intensivos em capital, em lotes empresariais têm sido consideravelmente mais efetivos na redução da pobreza do que os sistemas tradicionais de pequenas propriedades (BANCO MUNDIAL, 2004, p. 71-72).

Apesar de o Banco Mundial (2004, p. 73) afirmar que "a presença de produtores empresariais é um fatorchave de sucesso dos projetos, contribuindo na definição dos cultivos, cadeias produtivas comerciais e logísticas [...]", contraditoriamente, reconhece a insustentabilidade desse modelo quando destaca a exaustão das águas subterrâneas em projetos de irrigação, inclusive na Chapada do Apodi, no Ceará. Além disso, menciona a possível contaminação ambiental por agroquímicos, tanto em águas superficiais como subterrâneas, em alguns projetos, questões já verificadas por outros estudos científicos.

\footnotetext{
A superexplotação da água subterrânea nos projetos Jaguaribe-Apodí e Gorutuba conduziu à exaustão dos aquíferos, ameaçando, assim, sua sustentabilidade; em alguns projetos, o uso inadequado de agro-químicos contaminou as águas superficiais e, possivelmente, também as subterrâneas. (BANCO MUNDIAL, 2004, p. 73)
}

Vale ressaltar que foi regulamentada a nova Lei de Irrigação, n. 12.787, de 2013, que fundamenta a Política de Irrigação, apontando como um dos seus objetivos "concorrer para o aumento da competitividade do agronegócio brasileiro" (MINISTÉRIO DA INTEGRAÇÃO NACIONAL, 2013). Como parte dessa estratégia foi lançada a segunda fase do Programa de Aceleração do Crescimento (PAC2), tendo como meta o investimento de recursos públicos da ordem de $\mathrm{R} \$ \mathbf{6 , 9}$ bilhões para a expansão dos perímetros irrigados, visando à ampliação da área abrangida pelos perímetros já existentes em 193.137 hectares e a instalação de novos perímetros em 200.000 hectares (PONTES; GADELHA; FREITAS et al., 2013). Isso significa que, se o cenário atual é preocupante em relação ao uso de agrotóxicos, esse quadro pode se agravar se a meta estabelecida pela Política Pública de Irrigação se efetivar. 
A implantação dos Perímetros Irrigados e as implicações do uso de agrotóxicos no Baixo Jaguaribe no contexto do avanço do Estado neoliberal no Ceará

No Baixo Jaguaribe ocorreu a primeira experiência da Política Nacional de Irrigação no estado do Ceará. Como resultante do avanço dos perímetros irrigados do Nordeste (FREITAS, 2010), o Ceará incorporou 14 perímetros públicos sob a atuação do DNOCS (Quadro 1), objetivando o planejamento regional, conforme demonstrou Oliveira (1981). Desse total, quatro perímetros irrigados foram implantados no Baixo Jaguaribe: o Perímetro de Morada Nova; o Perímetro Irrigado de Jaguaruana; o Perímetro Irrigado JaguaribeApodi; e o Perímetro Irrigado Tabuleiros de Russas.

Os perímetros Jaguaribe-Apodi e Tabuleiros de Russas integram a nova fase da Política de Irrigação, incorporando lotes empresariais, ou seja, do agronegócio. Já o de Morada Nova e Jaguaruana foram construídos na fase inicial dos projetos de irrigação, atendendo a agricultura de base familiar, embora tenha expropriado parte dos camponeses desapropriados à época (FREITAS, 2010).

A estratégia do Estado no Ceará de apoio a essa política nacional e ao modelo de agronegócio se deu a partir da criação da Secretaria de Agricultura Irrigada, em 1999 (FREITAS, 2010). 0 governo estadual instituiu, em 1998, a Coordenação da Agricultura Irrigada do Ceará, sob o comando de um empresário ligado ao agronegócio, nomeado um ano depois para a referida Secretaria.

Além disso, foi elaborado o Programa Cearense de Agricultura Irrigada -PROCEAGRI, que estabeleceu, dentre seus projetos, o Agropolos, concebido nas mesmas características do empreendimento integrado, do Programa Brasil em Ação, do governo federal à época, visando a um ambiente de parceria e cooperação empresa-Estado. De acordo o programa, foram definidos seis Agropolos de atuação no Ceará: metropolitano; Baixo-Jaguaribe; Ibiapaba; Baixo-Acaraú; Centro-Sul; e, Cariri. O apoio à comercialização e à exportação constituíram algumas das ações do Agropolos, voltadas ao agronegócio de frutas, flores etc. (SABADIA et al., 2006).

Esses programas e ações do Estado cearense apresentam forte apelo aos parâmetros neoliberais, principalmente em relação aos mandatos do governo de Tasso Jereissati (1995-2002), do PSDB; seguido de Cid Ferreira Gomes (2007-2014), do PSB/PROS, atualmente vinculado ao $\mathrm{PDT}$, pautados na parceria público-privada e na articulação com o mercado internacional, postura que tem se mantido no governo de Camilo Santana, do PT (2015-atual), embora com algumas especificidades diferenciadas.
Atualmente foi criada a Secretaria do Desenvolvimento Econômico (SDE), por meio da Lei n. 15.773, de 10 de março de 2015, de acordo com o Decreto n. 31.6791, de 23 de março de 2015. Dentre os objetivos da SDE destacamse: aprovar e acompanhar projetos de investimentos no setor de indústria, comércio, turismo e agronegócio de médio e grande porte; avaliar a possibilidade quanto à formatação de projetos de infraestrutura concebidos na forma de parcerias público-privadas (Programa PPP); desenvolver e fomentar a promoção comercial de âmbito nacional e internacional; avaliar e monitorar a política de incentivos fiscais, financeiros ou tributários do Estado; planejar e desenvolver programas de apoio e incentivos aos pequenos negócios, dentre outros ${ }^{3}$.

Com a finalidade de executar as políticas e diretrizes oriundas da SDE, o governo criou a Agência de Desenvolvimento do Estado do Ceará (ADECE), competindo à mesma a execução da política de desenvolvimento econômico, industrial, comercial, de serviços, agropecuário e de base tecnológica, articulando-se com os setores produtivos e atraindo e incentivando investimentos, além de criar condições para a competitividade dos setores econômicos do Estado do Ceará, atuando nas áreas de mineração, indústria, agronegócio empresarial, comércio, serviços e energia4.

A ADECE tem utilizado os números das exportações do agronegócio para justificar as ações e os incentivos do Estado, porém, desconsidera completamente a socialização das perdas e seus impactos negativos no estado. É notório o crescimento das exportações das frutas (e da água), principalmente para o mercado europeu. Segundo a referida Agência, as exportações de frutas cearenses passaram de US\$ 3,224 em 2000, para US\$131,604 milhões no ano de 2008 , tendo um decréscimo em 2012, mas, mesmo assim, atingiu o montante de US\$108,1 milhões. As principais culturas exportadas referentes ao ano de 2012 foram: melão (72\%); banana $(9,1 \%)$; melancia $(8,5 \%)$; manga $(4,1 \%)$; mamão $(0,9 \%)$; e outras frutas $(4,8 \%)$. Já os mercados para esse mesmo período foram: Holanda, Reino Unido, Espanha, Alemanha, Itália, Estados Unidos, Irlanda e Canadá (ADECE, 2013).

Vale salientar, entretanto, que o volume da produtividade e lucratividade do agronegócio nas áreas de perímetros de irrigação e agropolos tem sido proporcional aos impactos negativos gerados, a exemplo daqueles

${ }^{3}$ De acordo com o site oficial do governo do estado. Disponível em: <http://www. cede.ce.gov.br/cede/paginas/legislacao-cede>. Acesso em: 8 abr. 2016

4Conforme apresentado no site oficial do governo do estado. Disponível em: <http://www adece ce gov.br/index php/sobre-a-adece? select wlcombo plus=http\%3A\%2F\%2Fwww.cede.ce.gov.br\%2F>. Acesso em: 8 abr. 2016 
QUADRO 1 - Perímetros públicos irrigados do Ceará (DNOCS).

\begin{tabular}{|c|c|c|c|c|c|c|c|}
\hline \multirow{2}{*}{$\mathbf{N}^{0}$} & \multirow{2}{*}{$\begin{array}{l}\text { Perímetro } \\
\text { irrigado }\end{array}$} & \multirow{2}{*}{ Município } & \multirow{2}{*}{ Fonte hídrica } & \multicolumn{2}{|c|}{ Área (ha) } & \multicolumn{2}{|c|}{ Implantaçāo/ano } \\
\hline & & & & $\begin{array}{c}\text { Desapro } \\
\text { priada }\end{array}$ & Implantada & Início & Operaçāo \\
\hline 1 & Araras Norte & $\begin{array}{c}\text { Varjota, } \\
\text { Reriutaba, Cariré }\end{array}$ & $\begin{array}{c}\text { Açude Paulo } \\
\text { Sarasate } \\
\end{array}$ & $6.407,39$ & $1.616,50$ & 1987 & 1998 \\
\hline 2 & $\begin{array}{l}\text { Ayres de } \\
\text { Souza }\end{array}$ & Sobral & $\begin{array}{l}\text { Rio Jaibaras } \\
\text { (afluente do } \\
\text { Rio Acaraú) } \\
\end{array}$ & $8.942,75$ & 615,00 & 1974 & 1977 \\
\hline 3 & Baixo-Acaraú & $\begin{array}{l}\text { Marco, Bela } \\
\text { Cruz, Acaraú }\end{array}$ & Rio Acaraú & $13.909,42$ & $8.335,00$ & 1983 & 2001 \\
\hline 4 & $\begin{array}{c}\text { Curu- } \\
\text { Paraipaba }\end{array}$ & Paraibapa & Rio Curu & $6.912,50$ & $3.004,14$ & 1974 & 1975 \\
\hline 5 & $\begin{array}{c}\text { Curu- } \\
\text { Pentecoste }\end{array}$ & $\begin{array}{l}\text { Pentecoste, Sāo } \\
\text { Luiz do Curu }\end{array}$ & $\begin{array}{l}\text { Açude General } \\
\text { Sampaio, } \\
\text { Açude Pereira } \\
\text { Miranda }\end{array}$ & $4.569,37$ & $1.068,00$ & 1974 & 1975 \\
\hline 6 & Ema & Iracema & Açude Ema & 352,03 & 42,00 & 1971 & 1973 \\
\hline 7 & Forquilha & Forquilha & $\begin{array}{c}\text { Açude } \\
\text { Forquilha }\end{array}$ & $3.327,13$ & 218,00 & 1974 & 1977 \\
\hline 8 & $\begin{array}{l}\text { Icó-Lima } \\
\text { Campos }\end{array}$ & Icó & $\begin{array}{c}\text { Açude Lima } \\
\text { Campos }\end{array}$ & $10.583,18$ & $2.712,00$ & 1969 & 1973 \\
\hline 9 & $\begin{array}{l}\text { Jaguaribe- } \\
\text { Apodi }\end{array}$ & $\begin{array}{l}\text { Limoeiro do } \\
\text { Norte e Quixeré }\end{array}$ & $\begin{array}{l}\text { Rio Jaguaribe } \\
\text { (através do } \\
\text { afluente Rio } \\
\text { Quixeré) }\end{array}$ & $9.605,71$ & $5.465,09$ & 1987 & 1989 \\
\hline 10 & Jaguaruana & Jaguaruana & Rio Jaguaribe & 343,08 & 231,31 & 1975 & 1977 \\
\hline 11 & Morada Nova & $\begin{array}{l}\text { Morada Nova } \\
\text { Limoeiro do } \\
\text { Norte }\end{array}$ & $\begin{array}{c}\text { Açude } \\
\text { Banabuiú e } \\
\text { Açude Pedras } \\
\text { Brancas } \\
\end{array}$ & $11.166,31$ & $4.474,19$ & 1968 & 1970 \\
\hline 12 & Quixabinha & Mauriti & $\begin{array}{c}\text { Açude } \\
\text { Quixabinha } \\
\end{array}$ & 530,35 & 293,00 & 1971 & 1972 \\
\hline 13 & $\begin{array}{c}\text { Tabuleiros de } \\
\text { Russas }\end{array}$ & $\begin{array}{c}\text { Russas, } \\
\text { Limoeiro do } \\
\text { Norte e Morada } \\
\text { Nova } \\
\end{array}$ & $\begin{array}{c}\text { Rio Jaguaribe } \\
\text { e Rio } \\
\text { Banabuiú }\end{array}$ & $18.915,00$ & $10.765,72$ & 1992 & 2004 \\
\hline 14 & Várzea do Boi & Tauá & $\begin{array}{c}\text { Açude Várzea } \\
\text { do Boi }\end{array}$ & $12.878,71$ & 326,00 & 1973 & 1975 \\
\hline \multicolumn{4}{|c|}{ Total } & $108.443,98$ & $52.689,31$ & - & - \\
\hline
\end{tabular}


oriundos do uso de agrotóxicos. Dentre esses impactos podem-se mencionar as intoxicações de trabalhadores rurais (assalariados) das empresas de agronegócio, de camponeses que produzem e residem nas comunidades internas e circunvizinhas aos perímetros irrigados, bem como em relação à contaminação ambiental, dentre outros.

\section{Implicações do uso de agrotóxicos no Ceará: intoxicações e contaminação ambiental no Baixo Jaguaribe}

As intoxicações e a contaminação ambiental são alguns dos impactos decorrentes do uso de agrotóxicos no Ceará, identificados por estudos científicos e através de levantamento realizados por órgãos do Estado, relacionados à saúde e ao gerenciamento dos recursos hídricos. Apresentaremos, nesse sentido, alguns dados das intoxicações decorrentes do uso de agrotóxicos, além de outros estudos relacionados a esse tema no referido estado, principalmente na região do Baixo Jaguaribe.

Com base em dados oficiais do Ministério da Saúde/ SINAN, analisamos as intoxicações por agrotóxicos de uso agrícola no Nordeste, mais especificamente no Estado do Ceará, por meio de mapeamento, evidenciando os municípios que apresentam os maiores índices de intoxicações, no período de 2007 a 2014 (Figura 1). As áreas dos estados nordestinos em que esse processo ocorre de forma mais intensa coincidem com as que incorporam a Política Nacional de Irrigação, coordenada pelo DNOCS, espaços de expansão do agronegócio. 0 quadro de intoxicações compreende também a faixa que se estende pelo rio São Francisco, incluindo os polos de irrigação sob a coordenação da Companhia do Desenvolvimento dos Vales do São Francisco e Parnaíba (CODEVASF).

O Ceará é um dos estados nordestinos que apresenta os maiores índices de intoxicações. Parte significativa dos municípios com os maiores índices de intoxicações incorpora a Política Nacional de Irrigação (DNOCS). As intoxicações por agrotóxicos de uso agrícola foram evidenciadas em $100 \%$ dos 20 municípios do Ceará que incorporam perímetros públicos irrigados coordenados pelo DNOCS (Figura 2).

Do total dos vinte municípios analisados no Ceará, três estão incluídos entre os que apresentam os maiores índices de intoxicações do estado, referindose aos municípios de Bela Cruz, Sobral e Varjota, correspondendo a faixa de 26,14 a 74,12 casos em relação à população do município, utilizando a escala de um para cada cem mil habitantes. Na sequência, encontram-se os municípios de Limoeiro do Norte, Morada Nova e Tabuleiros de Russas (faixa de 19,05 a 26,13 casos); Quixeré, Acaraú, Paraipaba, Forquilha, Reriutaba e Cariré (faixa de 14,32 a 19,04 casos). Nesses municípios encontram os Perímetros Irrigados Araras Norte, Ayres de Souza e Baixo-Acaraú, Jaguaribe-Apodi, Morada Nova, Curu-Paraipaba, Forquilha e Araras Norte, sendo que alguns perímetros incorporam mais de um município (FREITAS, 2017).

No Baixo Jaguaribe, os municípios que apresentam os maiores índices de intoxicações (Limoeiro do Norte, Quixeré e Russas) correspondem a espaços de expansão do agronegócio, principalmente de fruticultura voltada para exportação (banana, melão, abacaxi, milho, sojasemente etc.). Morada Nova, por sua vez, trata-se de um perímetro com predominância de agricultura camponesa que incorporou o pacote tecnológico da "revolução verde" na produção de rizicultura irrigada, passando a conviver com a sujeição da renda da terra camponesa via comércio de agrotóxicos (FREITAS, 2017).

Esses dados dialogam com outros estudos realizados no Ceará, demonstrando os riscos dos agrotóxicos para a saúde e o ambiente. Uma dessas pesquisas vem sendo desenvolvida pela Universidade Federal do Ceará (UFC) no Baixo Jaguaribe desde o ano 2007, mostrando intensa exposição do ponto de vista ocupacional, em relação aos agrotóxicos, gerando níveis elevados de intoxicações, o que remete a um grave problema de saúde pública.

A pesquisa da UFC mostra que em três municípios do Baixo Jaguaribe (Limoeiro do Norte, Russas e Quixeré), que incorporam o agronegócio e os perímetros irrigados Tabuleiros de Russas e Jaguaribe-Apodi, foi evidenciada que a taxa de mortalidade por câncer é 38\% maior neles quando comparados a outros 12 municípios-controle da região que desenvolvem agricultura de sequeiro (RIGOTTO; SILVA; FERREIRA et al., 2013). Esses dados foram apresentados também em Rigotto (2011, p. 127):

Comparando os municípios de Limoeiro do Norte, Quixeré e Russas, onde avança há dez anos o agronegócio da fruticultura irrigada para exportação, com outros doze municípios do Ceará pareados por população e que desenvolvem apenas agricultura de sequeiro, com pequeno uso relativo de agrotóxicos, verificamos que a taxa de mortalidade por neoplasias foi 38\% maior nos municípios onde está o agronegócio, assim como a taxa de internações por abortos foi $40 \%$ maior neles, entre outros indicadores relevantes para os diversos efeitos crônicos dos agrotóxicos.

Outro estudo realizado na mesma região por Gama, Oliveira e Cavalcante (2013) evidencia elementos

5Pesquisa coordenada pela professora Dra. Raquel Maria Rigotto, intitulada "Estudo epidemiológico da população da região do Baixo Jaguaribe exposta à contaminação ambiental em área de uso de agrotóxicos", contemplada no edital: MCT-CNPq/MS-SCTIE-DECIT/CT - Saúde - N 24/2006. 
Figura 1 - Intoxicações por agrotóxicos de uso agrícola no Nordeste e no Ceará.

INTOXICAÇÃO POR AGROTÓXICOS DE USO AGRÍCOLA/Perímetros Irrigados do Nordeste/Ceará (DNOCS)

CEARÁ INTOXICAÇÃO POR AGROTÓXICO DE USO AGRÍCOLA

Municípios (2007-2014)
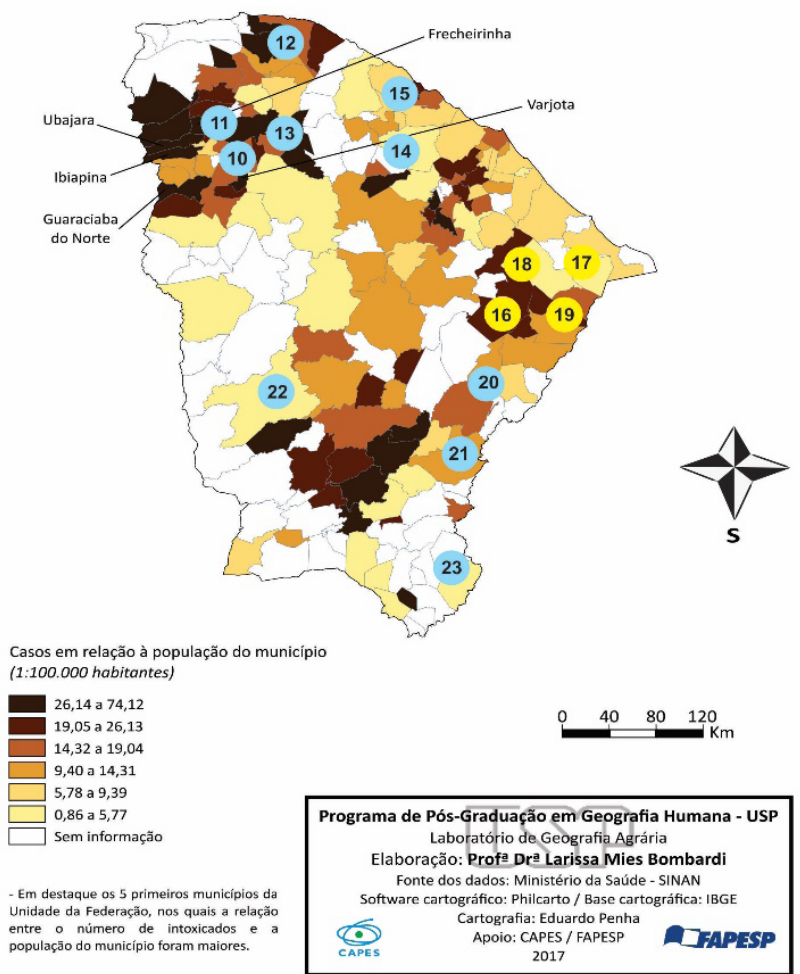

NORDESTE INTOXICAÇÃO POR AGROTÓXICO DE USO AGRÍCOLA
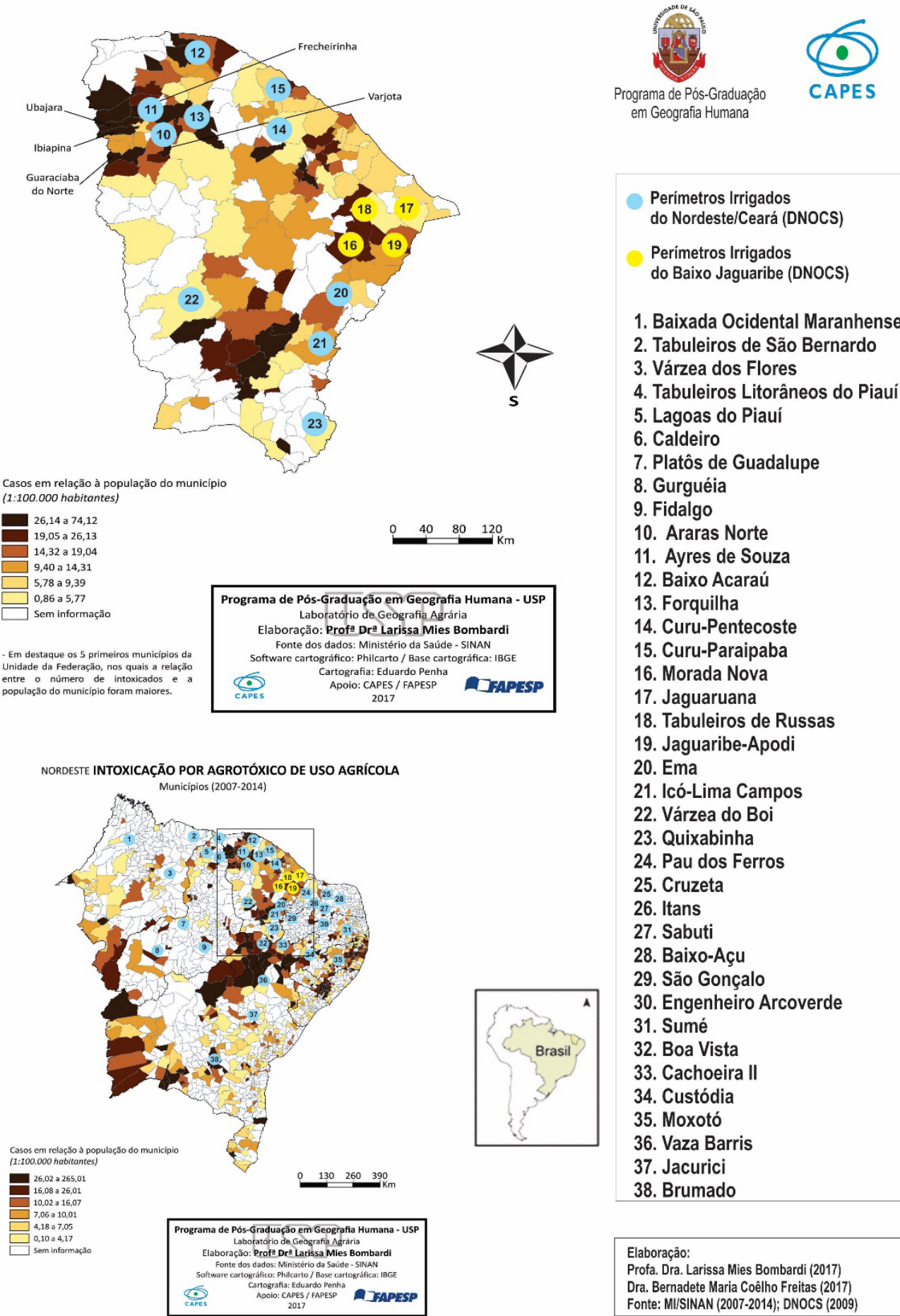

Perímetros Irrigados

do Nordeste/Ceará (DNOCS)

Perimetros Irrigados

do Baixo Jaguaribe (DNOCS)

1. Baixada Ocidental Maranhense

2. Tabuleiros de São Bernardo

3. Várzea dos Flores

4. Tabuleiros Litorâneos do Piauí

5. Lagoas do Piauí

6. Caldeiro

7. Platôs de Guadalupe

8. Gurguéia

9. Fidalgo

10. Araras Norte

11. Ayres de Souza

12. Baixo Acaraú

13. Forquilha

14. Curu-Pentecoste

15. Curu-Paraipaba

16. Morada Nova

17. Jaguaruana

18. Tabuleiros de Russas

19. Jaguaribe-Apodi

20. Ema

21. Icó-Lima Campos

22. Várzea do Boi

23. Quixabinha

24. Pau dos Ferros

25. Cruzeta

26. Itans

27. Sabuti

28. Baixo-Açu

29. São Gonçalo

30. Engenheiro Arcoverde

31. Sumé

32. Boa Vista

33. Cachoeira II

34. Custódia

35. Moxotó

36. Vaza Barris

37. Jacurici

38. Brumado 
Figura 2 - Intoxicações por agrotóxicos de uso agrícola no Ceará.

CEARÁ - PESSOAS INTOXICADAS POR AGROTÓXICOS DE USO AGRÍCOLA (2007-2014) MUNICÍPIOS QUE INCORPORAM PERÍMETROS IRRIGADOS (DNOCS)
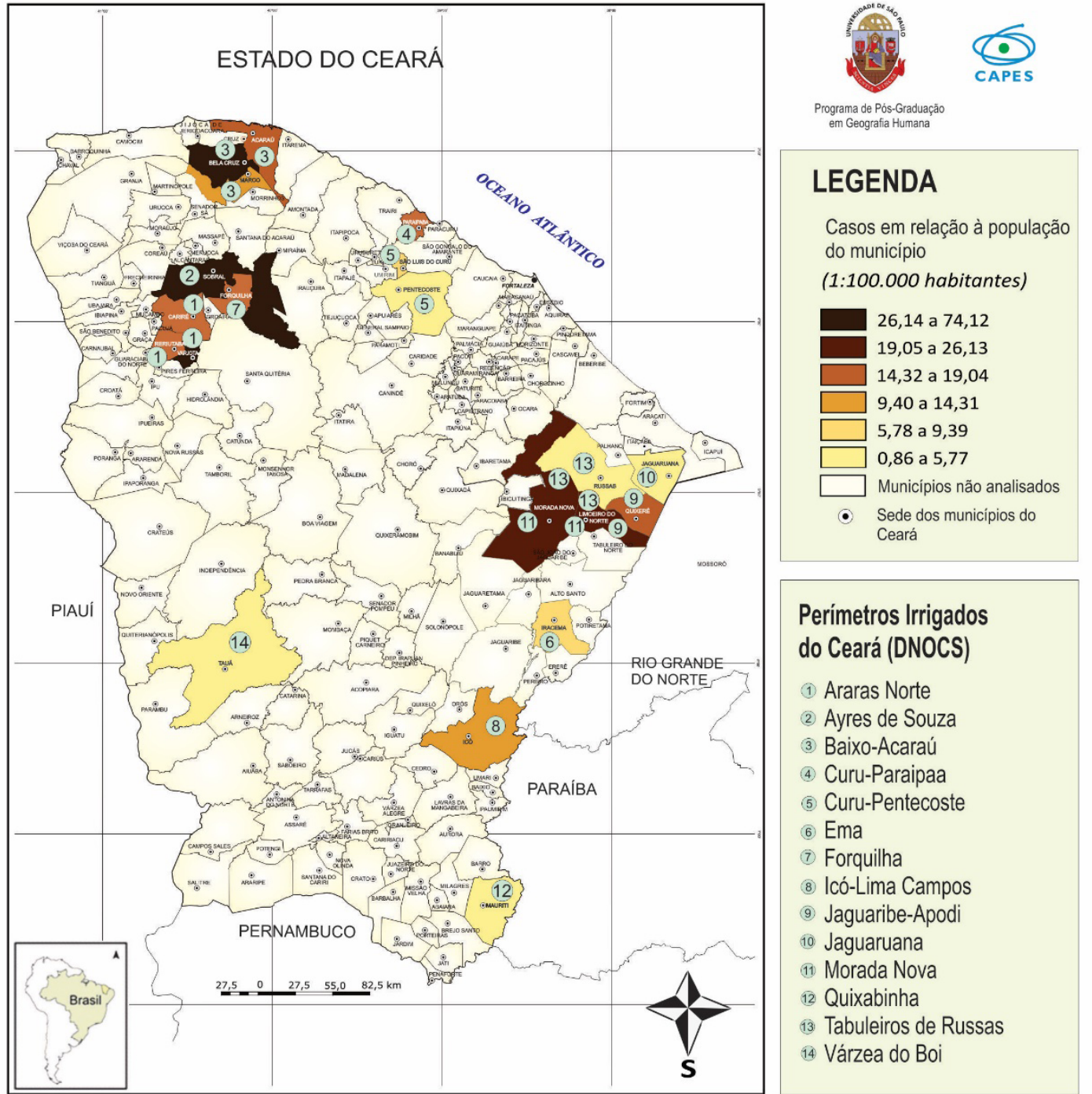

Perímetros Irrigados do Ceará (DNOCS)

(1) Araras Norte

(2) Ayres de Souza

(3) Baixo-Acaraú

(4) Curu-Paraipaa

(5) Curu-Pentecoste

(6) Ema

(7) Forquilha

(8) Icó-Lima Campos

(9) Jaguaribe-Apodi

(10) Jaguaruana

(11) Morada Nova

(12) Quixabinha

(13) Tabuleiros de Russas

14 Várzea do Boi 
bastante alarmantes, referindo-se à quantidade $\mathrm{e}$ heterogeneidade de princípios ativos de agrotóxicos utilizados no Baixo Jaguaribe, incluindo os mais perigosos e persistentes ao ambiente. A problemática é atribuída pelos autores ao avanço do agronegócio, apoio aos pequenos e médios agricultores e, sobretudo, pela isenção de impostos ofertada pelo Estado.

Através dos dados foi verificado o uso de 201 produtos
agrícolas produzidos por 21 empresas (...). Foram
verificados 148 princípios ativos com classe química
definida e 2 compostos denominados de óleos mineral
e vegetal, os quais podem estar presentes de forma
unificada ou através de misturas contento dois ou
até três princípios ativos por produto agrícola (...).
Os princípios ativos abamectina, alfa-cipermetrina,
ametrina, atrazina, clorotalonil, clorpirifós, diurom,
glifosato, imidacloprido e tiofanato-metílico
apresentam-se como os mais frequentes nos
produtos agrícolas utilizados na região estudada
(...) Todos são das classes toxicológica e ambiental
I e II, demonstrando que a adoção por agrotóxicos
mais perigosos é a principal alternativa na região
(...) As culturas predominantes com mais de 1.000 ha
em área de plantio são arroz, banana, milho e feijão
(...) O grande número de agrotóxicos administrados
nessa região é reflexo do aumento da área de plantio,
impulsionado pelo crescimento no agronegócio e pela
melhoria e incentivos ao médio e pequeno agricultor
e, principalmente, pela isenção de impostos. A análise
mostrou uma nova realidade no semiárido nordestino,
uma vez que nas décadas de 80 e 90 poucas lojas de
produtos agrícolas eram encontradas na região e o uso
de agrotóxicos era reduzido e limitado a poucas marcas
e princípios (...) A diversificação de produtos agrícolas
administrados na região estudada, bem como dos
princípios ativos, é bem maior quando comparada com
estudos nas regiões Sul e Sudeste. Isso torna a região
dos perímetros de irrigação dos municípios de Russas,
Morada Nova, Limoeiro do Norte e Quixeré um dos
maiores e mais diversificados no uso de agrotóxicos no País. (GAMA; OLIVEIRA; CAVALCANTE, 2013, p. 464)

Observa-se que o uso de agrotóxicos na região do Baixo Jaguaribe tem ampliado também por parte dos camponeses, embora o maior volume seja utilizado pelo agronegócio (RIGOTTO, 2011), quadro que não se diferencia do restante do País. 0 uso de agrotóxico pela pequena propriedade no Brasil tem sido resultante da subordinação da renda da terra camponesa ao capital, conforme foi identificado em trabalho anterior (BOMBARDI, 2011, p. 1-2):

Se analisarmos o consumo de agrotóxicos pelas pequenas propriedades, de acordo com o Censo Agropecuário de 2006 (IBGE), verificaremos que dentre aquelas que têm entre 0 e 10 hectares, $23,7 \%$ utilizaram agrotóxicos e $2,9 \%$, embora não tivessem utilizado no ano do Censo, costumam utilizar. Isto significa que dentre as menores propriedades do Brasil, $27 \%$ lançam mão do uso de agrotóxicos. Já entre as propriedades que têm entre 10 a 100 hectares, a porcentagem daquelas que utilizaram agrotóxicos no ano do Censo alcançou $33,2 \%$, se consideradas aquelas que utilizam, mas não utilizaram no ano do Censo, este número chega a $36 \%$. Estes dados são reveladores de um intenso processo de subordinação da renda da terra camponesa ao capital monopolista: mais de 1/3 das pequenas propriedades no Brasil utilizam venenos.

No Baixo Jaguaribe, a sujeição da renda da terra pelo capital comercial é relatada por alguns camponeses, a exemplo de irrigantes ${ }^{6}$ de base familiar, do Perímetro Irrigado de Morada Nova, que reclamam da sujeição da renda da terra camponesa (MARTINS, 1981) por parte das empresas que comercializam agrotóxicos na região (FREITAS, 2017). Os camponeses relatam também os efeitos desse veneno desde o início da implantação do projeto que desenvolve, principalmente, a rizicultura e as pastagens.

Aqui a renda fica mais com os atravessadores (...) Até 94 tinha o financiamento bancário. Antes era só as cooperativas (...) Aí houve uma inadimplência. Aí o que foi que aconteceu, aquelas pessoas terceiros começaram a entrar, fornecendo ureia, máquina. A venda até que é mais livre, o que é mais preso é o fornecimento de insumos e máquinas (...) São empresas variadas (...) Aí, por exemplo, um saco de adubo hoje, de fertilizante, de ureia custa 70 reais, é passado por irrigante a $90,100,120$ reais, a um preço bem alto. Por quê? Porque os irrigantes não teem o recurso pra pagar. Eles fornecem pra 150 dias (...). Aqui teve até irrigante que morreu (...). (CAMPONÊS IRRIGANTE DO PERÍMETRO IRRIGADO DE MORADA NOVA, 2015)

Aqui a gente usa muito.(...) Quando dá bom a gente tira uns 20 mil reais. Desse total, uns 9 ou 10 mil é só pra lojas de insumos. Só de agrotóxicos é uns 2 mil reais, isso sem os fertilizantes pro preparo do solo (...) Agora, se você for comprar à vista, gasta só uns 7 mil de insumos. (...) Nós aqui não temos outro jeito. Às vezes já devemos no banco. Eu peguei no banco do PRONAF. Cheguei lá pra pagar aí não receberam por conta de umas burocracias(...) Aí tivemos uma praga de rato, tive que gastar o dinheiro todo e fiquei com a conta no banco pra pagar. (CAMPONÊS IRRIGANTE DO PERÍMETRO IRRIGADO DE MORADA NOVA, 2017)

No Ceará, a expansão do agronegócio e dos impactos do uso de agrotóxicos tem motivado a reação de camponeses, movimentos sociais, universidades, entidades vinculadas à igreja católica, sindicatos e parlamentares, que denunciam e reivindicam alternativas, no sentido de construir políticas públicas que incentivem agricultura camponesa de base agroecológica e, ao mesmo tempo, coíbam o uso de agrotóxicos no estado.

É nesse sentido que vem ocorrendo um movimento contra a pulverização aérea no Ceará, iniciado pelo ativista Zé Maria do Tomé, cuja luta resultou na elaboração e aprovação da Lei n. 1478/2009, que dispõe sobre a proibição do uso de aeronaves nas pulverizações de lavouras. A referida Lei foi revogada pela Câmara Municipal de Limoeiro do Norte, sob a pressão das empresas do agronegócio, logo após o assassinato

${ }^{6} \mathrm{O}$ termo irrigante é utilizado para designar aqueles que desenvolvem agricultura nos perímetros públicos irrigados, que podem ser de porte familiar e médios produtores. O agronegócio, por sua vez, é representado, em geral, pelas empresas agrícolas, nacionais e multinacionais. 
desse ativista em 21 de abril de 2010, que também denunciava a grilagem de terras no projeto JaguaribeApodi, problemática evidenciada por DNOCS (2009).

Atualmente, um novo projeto de Lei (n. 18/2015), de autoria do deputado estadual Renato Roseno (PSOL) tramita na Assembleia Legislativa do Ceará e pretende proibir a pulverização aérea dos venenos agrícolas. A nova Lei questiona também as isenções relacionadas ao comércio de agrotóxicos no estado, problemática discutida em Audiência Pública realizada na referida Assembleia, em abril de 2015. Na ocasião, uma camponesa apresentou alguns impactos da pulverização aérea na Chapada do Apodi, destacando o papel do ativista Zé Maria do Tomé em sua comunidade:

Quando o avião passava expurgando nossa comunidade parecia que estava nevando (...) Quatro horas da tarde, a gente olhava pra comunidade, via tudo branco. Nem a igreja a gente não via. Muitas galinhas faleceram, muitos animais faleceram. Eu digo isso porque eu tinha no meu quintal 120 galinhas e 80 galinhas morreram numa tarde só, quando o avião passou expurgando. Isso aconteceu no quintal da minha casa. Por isso é que a gente fala contra os agrotóxicos. $\mathrm{E}$ a gente tem ainda o caso de doença. $\mathrm{E}$ aí eu lembro do companheiro Zé Maria que ele dizia - daqui a dez anos talvez eu não esteja vivo, mas vocês vão estar pra ver o número de câncer em nossa população; o número de crianças que vão nascer com má-formação. E a gente já tem um número altíssimo de casos de câncer em nossa comunidade. De janeiro até março nasceram quatro crianças com má-formação (...). (SOCORRO, COMUNIDADE DO TOMÉ, AUDIÊNCIA PÚBLICA, 24 DE ABRIL DE 2015)

Além da questão dos agrotóxicos, os movimentos sociais, os(as) camponeses(as) e as demais entidades e universidades cobram do Estado a punição pelo crime cometido contra o ativista da região que, segundo denúncia do Ministério Público Estadual, envolve um empresário do ramo da banana da Chapada do Apodi. A questão tem sido amplamente divulgada, inclusive na imprensa nacional e internacional, frente à violência no campo e os danos gerados pelos agrotóxicos no Ceará, mais especificamente no Baixo Jaguaribe.

\section{Considerações finais}

De acordo com esta análise, observa-se que estamos diante de um grave problema de saúde pública no Brasil, decorrente do uso de agrotóxicos, fruto do modelo de agricultura adotado no País, a partir da segunda metade do século XX. Esse processo tem intensificado nos últimos anos, quadro que tornou o País o maior consumidor de agrotóxicos do mundo, implicando o aumento dos índices de contaminação, intoxicações, dentre outros.
Com base nos dados analisados neste estudo, verificamos que os espaços nordestinos mais atingidos pelas intoxicações por agrotóxicos de uso agrícola coincidem com as áreas de implantação da Política Nacional de Irrigação e de expansão do agronegócio. Portanto, há elementos que apontam para uma correlação entre a Política de Irrigação e o uso e as intoxicações por agrotóxicos nessas áreas, como é o caso do Ceará. Os sujeitos sociais mais atingidos pelos agrotóxicos na área estudada correspondem aos trabalhadores rurais (assalariados) das empresas do agronegócio, os camponeses e os residentes nas comunidades rurais circunvizinhas aos perímetros irrigados. Além desses, os consumidores são também afetados, no campo e na cidade, pela contaminação dos alimentos e derivados.

No caso dos camponeses, além de terem sua saúde afetada pelo uso de agrotóxicos na região, são prejudicados na medida em que utilizam esses venenos em função da ampliação da sujeição da renda da terra camponesa ao capital comercial, industrial e financeiro. Ressaltando que esse processo é resultante do incentivo do Estado, visando à expansão da agricultura capitalista no campo.

Nesse sentido, percebe-se a ampliação de áreas vinculadas à Nova Política Nacional de Irrigação e ao agronegócio no País, além de maior flexibilidade das legislações relacionadas aos agrotóxicos, questões que podem agravar o quadro atual. Isso reflete uma escolha do Estado que considera o crescimento econômico à frente das questões sociais e ambientais. Entretanto, tem crescido o enfrentamento ao uso de agrotóxicos por meio da luta de camponeses que se unem a outros movimentos e entidades como a Universidade, com intuito de buscar alternativas para o campo.

Isso faz crer, com base na análise dos dados apresentados, que o Estado brasileiro deve priorizar políticas públicas para o campo conjugadas com a não utilização de agrotóxicos, implantando de imediato políticas de redução do uso de agrotóxicos, a exemplo do Programa Nacional para Redução do Uso de Agrotóxicos (PRONARA). No caso do Ceará, a lei de proibição da pulverização aérea e o fim dos incentivos ao comércio dos agrotóxicos constituem-se questões fundamentais para que esse processo avance. A efetivação de políticas públicas que priorizem a agricultura camponesa agroecológica torna-se imprescindível no Brasil, pela possiblidade de relação mais saudável com a natureza e por fortalecer a justiça social no campo. 


\section{Referências}

ADECE (AGÊNCIA DE DESENVOLVIMENTO DO ESTADO DO CEARÁ). Perfil da produção de frutas Brasil, Ceará 2013. (2015). Disponível em: <http://www.adece.ce.gov.br/index.php/downloads/category/7-projeto-leite-ceara?download $=28 \% 3$ Aestrategias - para-o-agronegocio-cearense $>$. Acessado em: 29 maio .

BANCO MUNDIAL. (2004). Impactos e externalidades sociais da irrigação no semiárido brasileiro. Brasília.

BOCHNER, R. (2007). Sistema Nacional de Informações Tóxico-Farmacológicas (Sinitox) e as intoxicações humanas por agrotóxicos no Brasil. Ciência e Saúde Coletiva. Rio de Janeiro, 12 (1), p. 73-89.

BOMBARDI, L. M. (2011). A intoxicação por agrotóxicos no Brasil e a violação dos direitos humanos. Direitos humanos no Brasil 2011: Relatório da Rede Social de Justiça e Direitos Humanos. São Paulo: Expressão Popular. Disponível em: <http://www.social.org.br/index.php/relatorios/relatorios-portugues/137-direitoshumanos-no-brasil-2011.html>. Acessado em: 11 ago. 2016.

(2013). Violência silenciosa: o uso de agrotóxicos no Brasil. Anais do VI Simpósio Internacional de Geografia Agrária: Universidade Federal da Paraíba. João Pessoa.

(2016). Pequeno ensaio cartográfico sobre o uso de agrotóxicos no Brasil. São Paulo: Laboratório de Geografia Agrária - USP. Blurb.

(2017). Geografia do uso de agrotóxicos no Brasil e conexões com a União Europeia. São Paulo: FFLCH: USP.

CARNEIRO, F. F.; ALMEIDA, V. S. de; TEIXEIRA, M. M.; BRAGA, L. de Q. V. (2011). Agronegócio x agroecologia: a busca pela justiça ambiental. In: RIGOTTO, R. (org.). Agrotóxicos, trabalho e saúde: vulnerabilidade e resistência no contexto da modernização agrícola no baixo Jaguaribe/CE. Fortaleza: Edições UFC, p. 584-612.

CARNEIRO, F. F.; AUGUSTO, L. G. da S.; RIGOTTO, R. M. et al. (orgs.). (2015). Dossiê ABRASCO: um alerta sobre os impactos dos agrotóxicos na saúde. Rio de Janeiro: EPSJV; São Paulo: Expressão Popular.

CHESNAIS, F. (1996). A mundialização do capital. São Paulo: Xamã.

(2000). Mundialização: o capital financeiro no comando. Tradução de Ruy Braga. [s/l]. Revista Les Temps Modernes, 607. Disponível em: <http://outubrorevista.com.br/wp-content/uploads/2015/02/Revista-Outubro-Edic\%CC\%A7a\%CC\%83o-5-Artigo-02.pdf>. Acessado em: 10 out. 2016.

DNOCS (DEPARTAMENTO NACIONAL DE OBRAS CONTRA AS SECAS). (2009). Levantamento agroeconômico social do Perímetro Irrigado Jaguaribe-Apodi. Fortaleza/CE (Relatório Técnico).

DINIZ, A. S. (2002). A construção dos perímetros irrigados e a criação de novas territorialidades no sertão. In: ELIAS, D.; SAMPAIO, J. L. F. (orgs.). Paradigmas da agricultura cearense. Modernização excludente. Fortaleza: Edições Demócrito Rocha, p. 37-60.

FREITAS, B. M. C. (2010). Marcas da modernização da agricultura do Perímetro Irrigado Jaguaribe-Apodi: uma face da atual reestruturação socioespacial do Ceará. 181 f. Dissertação (Mestrado em Geografia) - Universidade Estadual do Ceará, Fortaleza.

(2011). Marcas do agronegócio no território da Chapada do Apodi. In: RIGOTTO, Raquel Maria (org.). Agrotóxicos, trabalho e saúde: vulnerabilidade e resistência no contexto da modernização agrícola no Baixo Jaguaribe/CE. Fortaleza: UFC; Expressão Popular, p. 144-165.

(2017). Campesinato, uso de agrotóxicos e sujeição da renda da terra ao capital no contexto da expansão da Política Nacional de Irrigação no Ceará. 2017. 325 f. Tese (Doutorado em Geografia Humana) - Universidade de São Paulo, São Paulo.

GAMA, A. F.; OLIVERIA, A. H. B.; CAVALCANTE, R. M. (2013). Inventário de agrotóxicos e risco de contaminação química dos recursos hídricos no semiárido cearense. Química Nova, vol. 36, n. 3, 462-467.

IGBE (FUNDAÇÃO INSTITUTO BRASILEIRO DE GEOGRAFIA E ESTATÍSTICA). (1990). Divisão regional do Brasil em mesorregiões e microrregiões geográficas. V. I. Rio de Janeiro: IBGE.

(2002). Divisão territorial brasileira. Rio de Janeiro: IBGE.

IPECE (INSTITUTO DE PESQUISA E ESTRATÉGIA ECONÔMICA DO CEARÁ). (2003). Cartografia. Disponível em: <http:// www.ipece.ce.gov.br/index.php/cartografia>. Acessado em: fev. 2003. 
LONDRES, F. (2011). Agrotóxicos no Brasil: um guia para ação em defesa da vida. Rio de Janeiro: AS-PTA - Assessoria e Serviços a Projetos em Agricultura Alternativa.

MACHADO, L. C. P.; MACHADO FILHO, L.C. P. (2014). A dialética da agroecologia: contribuição para um mundo com alimentos sem veneno. São Paulo: Expressão Popular. 360 p.

MARTINS, J. de S. (1981). Os camponeses e a política no Brasil: as lutas sociais no campo e seu lugar no processo político. Petrópolis/RJ: Vozes.

MINISTÉRIO DA AGRICULTURA, PECUÁRIA E ABASTECIMENTO. (2016). Decreto n. 4.074, de 4 de janeiro de 2002. Regulamenta a Lei n. 7.802, de 11 de julho de 1989. Disponível em: <http://sistemasweb.agricultura.gov.br/sislegis/action/ detalhaAto.do?method=recuperarTextoAtoTematicaPortal\&codigoTematica=1264996>. Acesso em: 21 de mar. 2016.

MINISTÉRIO DA INTEGRAÇÃO NACIONAL. (2008). A irrigação no Brasil: situação e diretrizes. Brasília: IICA.

(2015). Lei n. 12.787, de 11 de janeiro de 2013. Dispõe sobre a Política Nacional de Irrigação. Disponível em: <http://www.planalto.gov.br/ccivil_03/_Ato2011-2014/2013/Lei/L12787.htm>. Acessado em: 30 maio. 2015.

MINISTÉRIO DA SAÚDE. (2016). Secretaria de Vigilância em Saúde. Departamento de Vigilância em Saúde Ambiental e Saúde do Trabalhador. Relatório de Agrotóxicos na ótica do Sistema Único de Saúde. Brasília: Ministério da Saúde, 2016. Disponível em: <http://bvsms.saude.gov.br/bvs/publicacoes/agrotoxicos_otica_sistema_unico_saude_ v1_t.1.pdf>. Acessado em: 20 mar. 2016.

OLIVEIRA, F. de. (1981). Elegia para uma re(li)gião: SUDENE, Nordeste. Planejamento e conflito de classes. 3. ed. Rio de Janeiro: Paz e Terra.

OLIVEIRA, A. U. de. (2015). A mundialização do capital e a crise do neoliberalismo: o lugar mundial da agricultura brasileira. Geousp - Espaço e Tempo (On-line), v. 19, n. 2, p. 229-245. Disponível em: <http://www.revistas.usp.br/ geousp/article/view/102776>. doi: <http://dx.doi.org/10.11606/issn.2179-0892.geousp.2015.102776>. Acessado em: 11 ago. 2016.

PERESA, F.; ROZEMBERGA, B.; ALVES, S. R. et al. (2001). Comunicação relacionada ao uso de agrotóxicos em região agrícola do Estado do Rio de Janeiro. Rev. Saúde Pública, 35(6), p. 64-70. Disponível em: <http://www.scielo.br/pdf/ rsp/v35n6/7069.pdf>. Acesso em: 5 set. 2016.

PONTES, A. G.; GADELHA D.; FREITAS, B. M. C.; RIGOTTO, R. M.; FERREIRA, M. J. M. (2013). Os perímetros irrigados como estratégia geopolítica para o "desenvolvimento" do semiárido e suas implicações à saúde, ao trabalho e ao ambiente. Ciência \& Saúde Coletiva, V. 18, núm. 11. ABRASCO: Rio de Janeiro, nov. 2013. Disponível em: <http://www. scielo.br/scielo.php?script=sci_arttext\&pid=S1413-81232013001100012>. Acessado em: 20 out. 2016.

RIGOTTO, R. M. (org.). (2011). Agrotóxicos, trabalho e saúde: vulnerabilidade e resistência no contexto da modernização agrícola no baixo Jaguaribe/CE. Fortaleza: Edições UFC.

RIGOTTO, R. M.; SILVA, A. M. C.; FERREIRA, M. J. M.; ROSA, I. F.; AGUIAR, A. C. (2013). Trends of chronic health effects associated to pesticide use in fruit farming regions in the state of Ceará, Brazil. Revista Brasileira de Epidemiologia, $v$. 16, p. 763-773. Disponível em: <https://www.ncbi.nlm.nih.gov/pubmed/24896288>. Acessado em: 20 de ago. 2015.

ROSA, I. F.; PESSOA, V. M.; RIGOTTO, R. (2011). Introdução: agrotóxicos, saúde humana e os caminhos do estudo epidemiológico. In: RIGOTTO, R. (org.). Agrotóxicos, trabalho e saúde: vulnerabilidade e resistência no contexto da modernização agrícola no baixo Jaguaribe/CE. Fortaleza: Edições UFC, p. 217-256.

SABADIA, F. R. B. et al. (2006). A experiência de agropolos no Ceará: impactos no agronegócio da agricultura irrigada. Fortaleza: Instituto Agropolos do Ceará.

SINAN (SISTEMA NACIONAL DE AGRAVOS DE NOTIFICAÇÃO). (2014). Ministério da Saúde. Disponível em: <http:// portalsinan.saude.gov.br/intoxicacao-exogena>. Acessado em: jan. 2014.

SOUZA, M. J. N. de; OLIVEIRA, P. V. de; GRANGEIRO, C. M. M. (2002). Análise geoambiental. In: ELIAS, Denise (org.). $O$ novo espaço da produção globalizada: o Baixo Jaguaribe. Fortaleza: Edições Demócrito Rocha. 